\title{
Historijsko-geografska osnova razvoja Pazina: kartografska analiza
}

\author{
Prethodno priopćenje \\ Preliminary communication \\ UDK 913(497.5 Pazin)(091)(084.3)
}

\begin{abstract}
$\mathrm{Na}$ temelju originalnih istraživanja autorica donosi pregled kartografskih izvora za povijest Pazina od njegove prve pojave u kartama 1525. godine sve do katastra s kraja 19. stoljeća kada dolazak željeznice najavljuje novo doba u njegovu razvoju. Analiza navedenih izvora donosi nove spoznaje o urbanoj povijesti Pazina i historijsko-geografskim uvjetima njegova razvoja.
\end{abstract}

Ključne riječi: Pazin, Pazinska knežija, historijska geografija, kartografski izvori

\section{Uvod}

Dazin je nastao kao srednjovjekovno urbano središte kontinentalnog dijela Istre. Razvio se na strateški istaknutom platou iznad ponora Pazinčice, u samom srcu istarskoga poluotoka, na križištu prometnih pravaca koje su povezivale Istru s unutrašnjošću kontinenta. lako se ne zna točno vrijeme njegova osnivanja, sasvim je izvjesno da je u prvim stoljećima svoga razvoja Pazin formiran kao pogranična vojna utvrda na razmeđi bizantskih i franačkih interesnih sfera. Nakon formiranja hrvatske države u koju je ušao samo istočni dio Istre, Pazin se ponovno našao u neposrednoj blizini granice. Utemeljenjem Pazinske knežije, feudalnog posjeda koji je od 1374. u posjedu Habsburgovaca, Pazin postaje važnom utvrdom na granici s Mletačkom Republikom. Okružen mletačkim posjedom na zapadu, istoku i jugu, Pazin se razvijao u kontekstu stalnih pograničnih sukoba i sporova s Rašporskim kapetanatom. Jedina prometna veza Pazinske knežije s Habsburškom Monarhijom odvijala se preko Učke i ćićarije. Zbog takvih historijsko-geografskih ograničavajućih uvjeta razvoja na rubnom prostoru Imperija, Pazin se sve do pada Mletačke Republike razvija prije svega kao strateški važna pogranična utvrda i upravno sjedište Knežije. Utvrda kao stoljetni okvir razvoja Pazina, bila je jedan od ključnih funkcionalnih čimbenika razvoja grada, ujedno dajući mu i dominantna fizionomska obilježja. Pad Mletačke Republike i povezivanje čitave Istre u širi geografski kontekst, omogućit će Pazinu značajniju valorizaciju njegovih gospodarskih i prometnih funkcija.

Usprkos iznimnoj strateškoj važnosti Pazina, njegovi kartografski izvori razmjerno su rijetki. Vojno kartiranje habsburških topografa bilo je prvenstveno usmjereno na granično područje s Osmanskim Carstvom, dok je granica s Mletačkom Republikom ostala u drugom planu. Rijetki podaci o prostornom razvoju Pazina i njegovom utvrđivanju stoga su iznimno dragocjeni, pri čemu planovi naselja i utvrda imaju osobitu važnost. Spomenuti planovi ujedno predstavljaju i najstarije kartografske izvore Pazina. Ovaj je rad pokušaj autorice da okupi sve kartografske izvore za povijest Pazina, a njihovom analizom pridonese novim saznanjima o povijesnom razvoju Pazina i historijsko-geografskim uvjetima njegova razvoja. 


\section{Prvi pisani i kartografski spomenici Pazina}

Prvi pisani spomen grada Pazina seže u daleku 983. godinu, kada ga car Oton II. spominje kao castrum Pisinum (Ivetić 1997: 6). Do prvog kartografskog spomena grada proći će preko pet stotina godina. Rijetki srednjovjekovni kartografski izvori bilježili su uglavnom obalne gradove Istre. Pravu prekretnicu u kartografskom poznavanju čitave Istre, osobito njezine unutrašnjosti, označio je upravo jedan Istranin, Pietro Coppo (1470.-1556.). Ovaj geograf i kartograf živio je i radio u Izoli. Kao Istranin, Coppo je najveći dio svojih istraživanja posvetio upravo Istri, gdje je obavljao dužnost mletačkog povjerenika za Istru. Karta Istre Pietra Coppa iz 1525. nastala temeljem njegovih terenskih istraživanja, prva je regionalna karta toga poluotoka (sl. 1) $)^{1}$. Označivši Pazin kao „Pisin“ prvi je put označio ime toga grada na jednoj karti. Južno od grada označio je Stari Pazin kao „Pisin Vechio“. No, važnost Coppove karte ne ograničava se samo na brojne istarske toponime koje prvi puta susrećemo u jednom kartografskom izvoru, već i u činjenici da je Coppo klasificirao sva istarska naselja s obzirom na njihove funkcionalne osobine u nekoliko skupina (gradovi, biskupska središta, trgovišta, utvrde, kašteli, sela i mala sela) omogućivši nam uvid u njihovu hijerarhijsku strukturu².

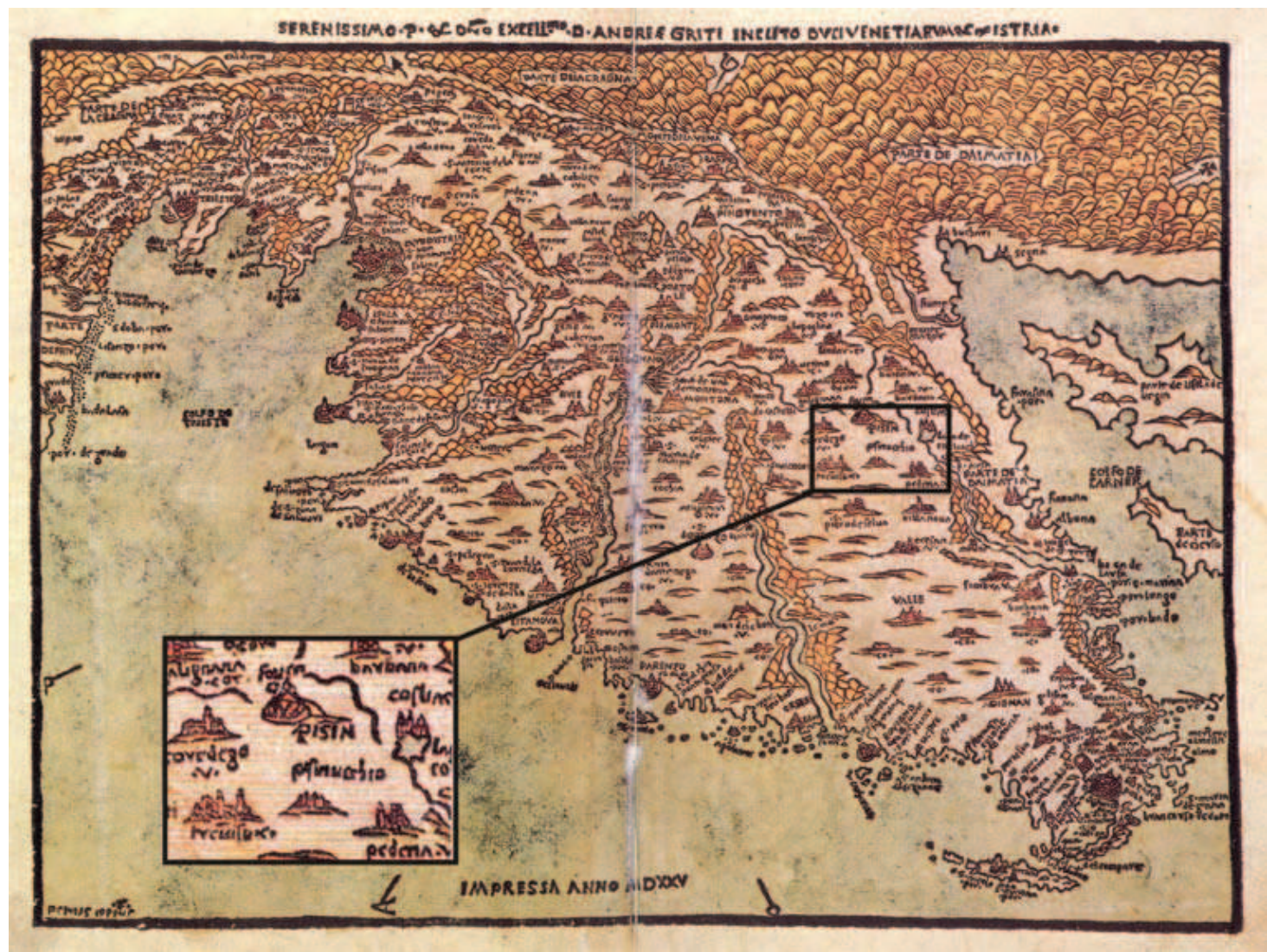

SI. 1 Karta Istre Pietra Coppa iz 1525. na kojoj je prvi put označen Pazin kao središnje utvrđeno naselje Knežije (Pomorski muzej Piran)

1 Osim naselja, Coppo je na karti označio solane, nekoliko mostova, grobove (sepulchri) te spilju (sepelunca) Svetog Servula kod Trsta koja je bila poznato hodočasničko odredište. U prikazu konture obale još uvijek se zapaža jak utjecaj srednjovjekovnih pomorskih karata - portulana. Originalna karta čuva se u Pomorskom muzeju „Sergej Mašera“ u Piranu.

2 Gradovi i biskupska središta su redovito označeni kao „città", trgovišta kao „terre“, utvrđeni gradovi označeni su velikim štampanim slovima, malim slovom „c“ označio je kaštele, dok slovom „"“ označava sela (ville). Naselja označena oznakom „co“ (vjerojatno od „contrada“) predstavljaju zaseoke. 
Temeljem Coppovih informacija možemo vidjeti da je u smislu hijerarhijske strukture naselja Knežija bila izrazito centralizirana. Pazin, jedino centralno naselje Knežije, označeno je kao grad-utvrda, dok su sva ostala naselja na istom prostoru označena kao više ili manje utvrđena mjesta (Žminj, Barban, Pićan, Kršan, Kožljak, Savičenta, Lupoglav, Tinjan, Lindar i Draguć). To nam jasno oslikava izrazito agrarnu strukturu Pazinske knežije te izrazit centralitet samog grada Pazina. No, Coppu se ipak potkrala jedna pogreška, nije istaknuo Pićan kao sjedište biskupije. Taj propust valja dovesti u vezu s činjenicom da je pićanski biskup, zbog vrlo lošeg stanja biskupskog dvora u Pićnu, uglavnom boravio u Pazinu.

Pazin se na kartama počinje pojavljivati upravo u vrijeme intenzivne modernizacije njegove utvrde. Činjenica da ga prvi put susrećemo na jednoj karti mletačke provenijencije, a ne habsburške kako bismo to s pravom mogli očekivati, nije slučajna. Pazin je bio najutvrđenije naselje Pazinske knežije i glavna prepreka mletačkom osvajanju unutrašnjosti Istre. Neposredno prije izrade ove karte, od 1508. do 1523. odvijao se rat između Austrije i Venecije u kojem je i Pazin znatno stradao (Bertoša 1995: 50). Izvješća iz 1534. govore o teškom stanju pazinskih utvrda. Od tada Austrija počinje posvećivati veću pažnju važnosti pazinske utvrde pa su pod nadzorom graditeljskog majstora Martina iz Lugana od 1537. do 1548. izvođeni radovi na izgradnji snažnog sjeverozapadnog krila na dva kata. Tada su pojačani i temelji istočnog, najizloženijeg krila. Ulazni je trijem nadsvođen kamenim svodom te je pored četvrtaste kule izgrađena kuhinja (Ivetić 1997: 8). Ubrzo nakon toga, Pazin se pojavljuje i na regionalnim habsburškim kartografskim prikazima. Prvi spomen naziva grada u njegovom hrvatskom obliku donosi upravo habsburški kartograf, Johanes Sambucus na svojoj karti llirika iz 1573., označivši grad i utvrdu kao „Pasin“.

No, o fizionomskoj i funkcionalnoj strukturi Pazina još uvijek ne saznajemo ništa. Općenito, kartografsko poznavanje unutrašnjosti Istre, u odnosu na njezin obalni dio bilo je znatno slabije. Čak i habsburški kartografi slabo su poznavali prostor Pazinske knežije pa se rijetki prikazi Istre uglavnom rade na temelju deskriptivnih izvora ili kompilacijom već postojećih karata. Vojni kartografi koji su karte izrađivali na temelju terenskog rada tijekom 16. stoljeća bili su zaokupljeni kartiranjem hrvatskih utvrda prema Osmanskom Carstvu.

\section{Prvi prikazi utvrde na vojnim fortifikacijskim planovima}

Prvi prikazi Pazina fortifikacijski su vojni planovi koji nam daju detaljan uvid u fizionomiju i strukturu pazinskih utvrda, izostavljajući istodobno sve elemente grada koji u obrambenom smislu nisu imali važnost. Tijekom 16. stoljeća Pazin obilazi čitav niz uglednih stručnjaka za fortifikacije koji su središnjim vlastima u Beču podnosili izvješća o stanju pazinskih utvrda. Među najstarijim do sada pronađenim izvješćima je ono Giovannia Antonia iz Gorice, koji je 1566. obišao Pazin i uz izvješće o njegovim obrambenim sposobnostima priložio i plan kaštela s dijelom gradskih zidina (sl. 2). Antonio je predlagao izdanju dodatnog bastiona kod okrugle kule koja bi štitila gradska vrata. Na glavnoj četvrtastoj kuli predlaže uređenje dodatne puškarnice. Na središnjem dijelu gradskog zida predlaže također uređenje dodatnog bastiona iz čijih puškarnica bi se kontrolirao prilazni put prema gradskim vratima (De Franceschi 1964: 186). Da bi bolje prezentirao puščane domete pojedinih puškarnica i bastiona, moguće puščane putanje dodatno je iscrtao snopovima linija. Zanimljivo je da će slično rješenje poboljšanja obrambenih sposobnosti Pazina gotovo stotinu godina kasnije predlagati glasoviti fortifikacijski inženjer Martin Stier. Ovakav prikaz Pazina, s potpuno izostavljenim elementima civilnog grada, jasno ukazuje na povijesni kontekst u kojem se Pazin razvija, teško opterećen stalnim sukobima s Mlečanima. 

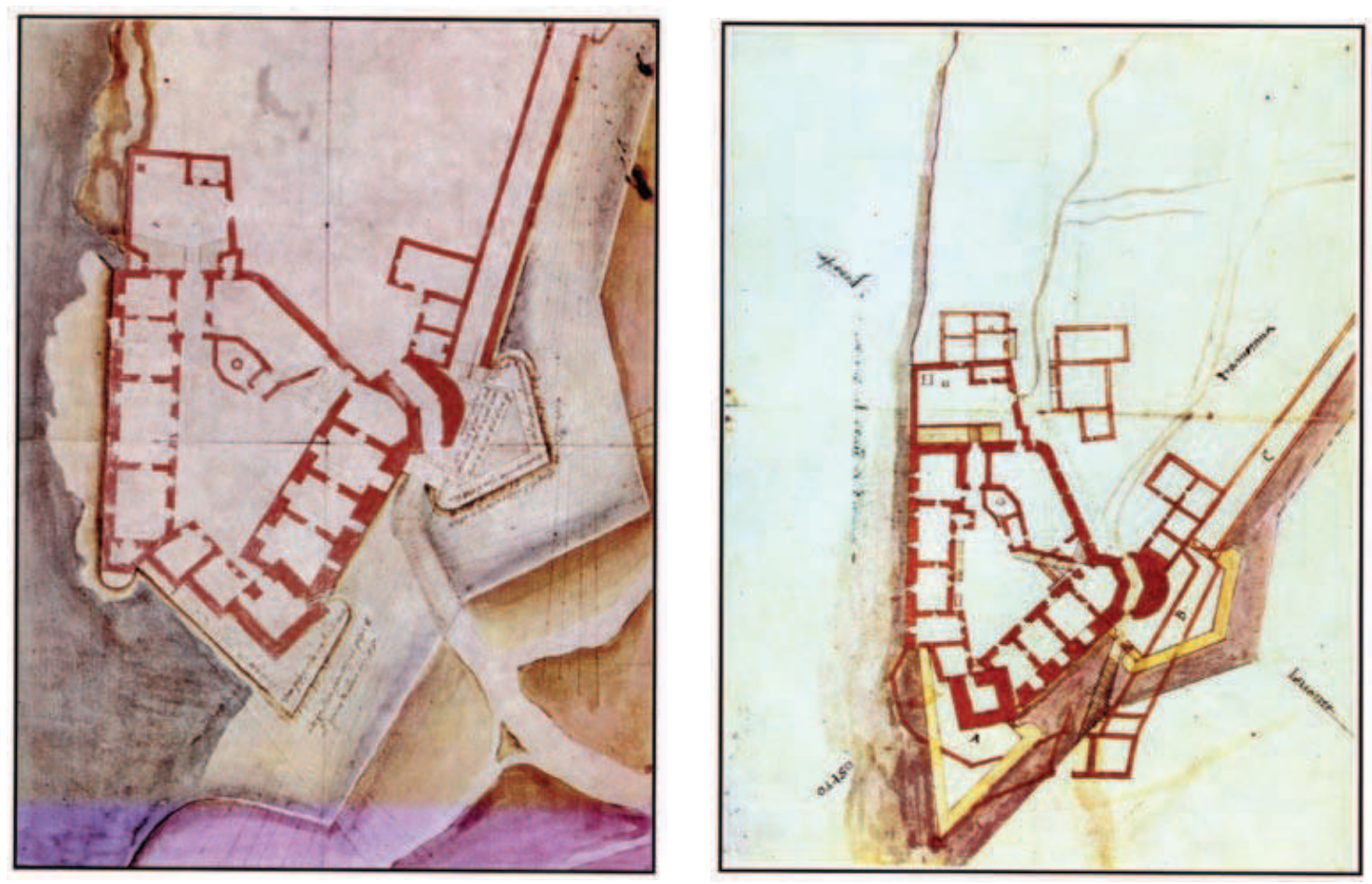

Sl. 2-3 Plan pazinskih utvrda Giovannia Antonia iz 1566. (lijevo) te plan Pazina nastao oko 1572. (desno) (preuzeto iz De Franceschi 1964)

Oko 1572. nastao je još jedan sličan plan pazinskih utvrda (sl. 3). Autor mu je Giacomo iz Lamberga (De Franceschi 1964: 189). Prilikom svoga obilaska izradio je plan utvrda s prijedlozima za dograđivanje. Giacomo je predlagao dodatnu bastionsku terasu, odnosno zemljano utvrđenje ispred četvrtaste i polukružne kule. Njegov projekt nikada nije realiziran, već je umjesto toga u blizini četvrtaste kule bio iskopan jarak. lako Giacomov prijedlog nije ostvaren, njegov plan dragocjen je izvor za rekonstrukciju izgleda Pazina u drugoj polovici 16. stoljeća. Pazin je imao tipičnu srednjovjekovnu fizionomiju s visokom četvrtastom kulom. Još krajem 15. stoljeća kaštel je na istočnom bloku dobio pojačanje dvostrukom pravolinijskom kurtinom. U tu svrhu je 1478. porušeno i nekoliko kuća koje su stajale preblizu utvrde. Tijekom 15. stoljeća uz unutrašnju stranu zida dograđene su štale, spremišta i cisterna te velika kuhinja. Dok je donji kat služio vojsci, gornji katovi imali su stambenu funkciju. Utvrdu su s tri strane čuvali duboki usjeci Pazinskog potoka i Jame, dok je jedini prilaz od strane grada kontroliran pokretnim mostom. Pazin 16. stoljeća dobro je čuvana utvrda.

Sedamnaesto je stoljeće bilo iznimno teško razdoblje u povijesti Istre. Uskočki rat (1615.1618.) te seljačke bune (osobito ona 1653.) teško su pogodili Pazinsku knežiju. Ratna razaranja potaknula su ponovnu potrebu obnova austrijskih utvrda u Istri, pa tijekom druge polovice 17. stoljeća Pazinsku knežiju opet obilaze habsburški vojni topografi i fortifikacijski inženjeri kako bi utvrdili stanje pazinskih utvrda i predložili mjere poboljšanja njihove obrambene funkcije. Neposredno nakon stišavanja seljačke bune 1657., Pazin obilazi habsburški vojni topograf Martin Stier. Kao rezultat njegova obilaska nastalo je pisano izvješće o stanju pazinskih fortifikacija te plan utvrda s prijedlozima njegovih dogradnji (sl. 4)3.

Plan zajedno s izvješćem danas se čuva u Nacionalnoj biblioteci u Beču (Österreichische National Bibliothek), Cod. 8608. 


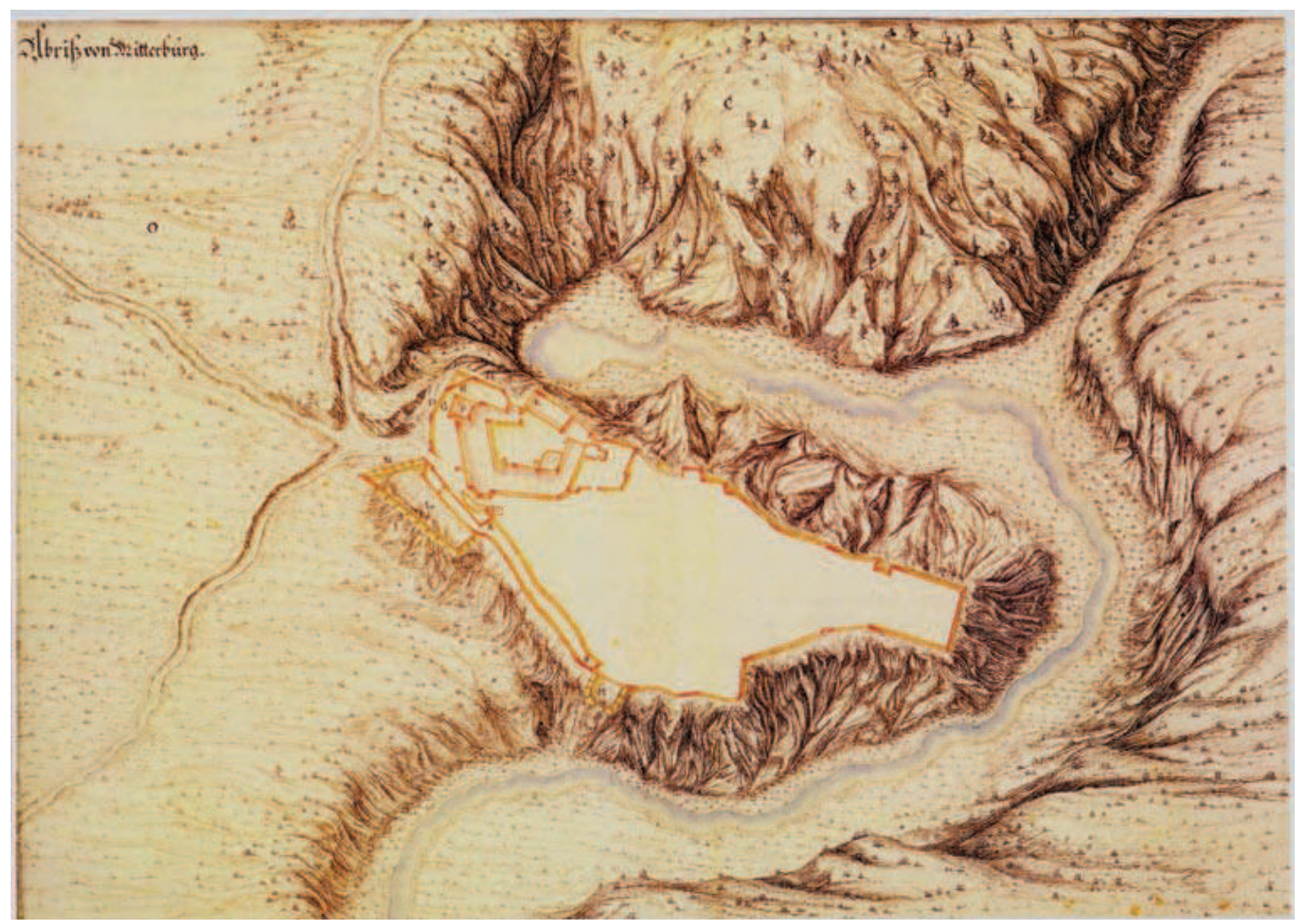

Sl. 4 Plan pazinskih utvrda s prijedlozima dogradnji, Martin Stier, 1657. (preuzeto iz Krmpotić 1998)

Dokument nosi naslov „Izvješće o dvorcu i gradiću Pazin, oba u posjedu Njegove Milosti Kneza od Auersperga, o njihovom sadašnjem stanju i mogućim poboljšanjima“. Izvješću je priložen plan pazinskih utvrda pod naslovom „Abriß von Mitterburg". Tekst izvješća donosimo u cijelosti (Krmpotić 1998: 143):

Pazin leži gotovo u sredini Istre, a okružen je mletačkim granicama. Većim dijelom leži na jednom brežuljku, pa je time neosvojiv osim na desnoj strani ulaza i dijelu zida od A do $B$. Na jednoj strani uzdiže se visoki brijeg (označen sa C), koji nadvisuje Pazin. No, zbog njegove prevelike visine i udaljenosti ne može se Pazinu topovima nanijeti veće štete. Osim toga, dolina između Pazina i spomenutog brijega je tako duboka, da ga je s te strane nemoguće osvojiti.

Kako Pazin na opisani način leži u sredini mletačkog područja, a Vaša Kraljevska Visost ne raspolaže u ovom kraju nikakvim bolje zaštićenim mjestom, to bi u slučaju kada bi došlo do rata s Mlečanima trebalo spremiti i osigurati pričuve, ne samo hrane nego i drugih potrepština. Osim toga, mogla bi se okolna zemlja obvezati za plaćanje ratnih doprinosa. Zbog toga držim potrebnim dobro se pobrinuti o mjestu i pomoći mu pri popravku slijedećih manjkavosti. Kao prvo, desno od gradskih vrata nalaze se dvije obrambene crte D i E, koje ni sa kojeg zida ne mogu biti obranjene. Tu se neprijatelj već pri prvom napadu pod njima može učvrstiti i tako dobiti mogućnost provaliti u zidine ili ih barutom dignuti u zrak. Isto bi se poslije toga moglo dogoditi s velikim tornjem $F$ čija je jedna strana $G$ nezaštićena. Tako bi toranj i dvorac mogli biti izgubljeni. Potrebno je stoga zid označen s E srušiti, a druga dva $G$ i $H$ produžiti te izgraditi kut I, kako bi se time sa zgrade $K$ jedna strana mogla štititi paljbom. No, da bi se druga strana, kao i dio zida od $A$ do $B$, obrambeno osigurali, treba podignuti utvrdu L i okrugli toranj $M$, ukoliko to položaj dopušta, a u tlorisu je žuto označeno s $N$. 
Označeni zid od L treba tako visoko podignuti, da bi se time čitavo zdanje moglo zaštititi od u neposrednoj blizini ležeće uzvisine O. S time bi bio dvorac doveden u zadovoljavajuće obrambeno stanje, uz izdatke od 3000 guldena.

Kod P se potok gubi u zemlju, a izvor je tu negdje u blizini. Budući da u dvorcu, kao i u gradiću, postoje samo jedna cisterna i dva zdenca, bilo bi za nuždu svrsishodno probiti jedan prolaz, kako bi se voda po noći i po potrebi mogla donositi izvana. Što se tiče posade, potrebno je Pazinu pri opsadi 300 pješaka i 50 konjanika.

Stierov plan omogućuje nam uvid u strukturu zidina utvrde kao i samog grada. Pri tome valja voditi računa da je čitav plan orijentiran na jug. Možemo vidjeti gradska vrata, kaštel s polukružnom i četvrtastom kulom te oblik gradskih utvrda. Stierov plan pazinskih utvrda priložen ovom izvješću prikazuje, ne samo postojeće stanje, već i predložene dogradnje. U cilju bolje obrane, Stier predlaže dogradnju dviju kula, jedne uz gradska vrata te jedne polukružne uz južni dio zidina. lako Stierovi prijedlozi nikada nisu realizirani, njegov plan Pazina ima još jednu osobitu vrijednost. Prvi nam put prikazuje Pazin u njegovom prirodnom okruženju, s prilaznim putovima, dolinom Pazinčice i njezinim ponorom, što nam omogućava sagledavanje topografskih uvjeta obrane, ali i izgradnje Pazina. Prometne komunikacije oko utvrde strogo su podređene njezinoj obrambenoj funkciji: utvrdi se prilazilo s njezine jugoistočne strane, strmom cestom s Buraja koja je išla kroz naselje sve do predzidina polukružne kule, vodeći dalje preko pokretnog mosta do polukružne kule te uz sjeverno krilo do vanjskog obzidanog dvorišta. U utvrdu se ulazilo preko pokretnog mosta koji je premošćivao jarak ispred ulaza na zapadnom pročelju.

Vanjska kontura zidina određena je dolinskim rubom potoka. Sam kaštel izgrađen je na najteže pristupnom dijelu, ponad same Jame. Gradu je moguće prići samo s jedne strane na koju je usmjerena sva obrambena snaga. Takva topografija terena činila je Pazin teško osvojivim gradom. Ovaj nam plan potvrđuje još jedan iščezli element nekadašnjeg prirodnog ambijenta Pazina, a to su njegove šume. Duž padine Pazinčice Stier je označio kontinuirani šumski pokrov, osobito u zoni oko same Jame. Nekadašnja šumovitost ovog kraja sačuvana je i u lokalnoj toponimiji, pa se kao naziv Pazinčice i područja oko nje često spominje i naziv "Lug“, označavajući tako šumovitu dolinu Pazinčice. Tako Stierov plan postaje značajan dokument ekohistorijskih uvjeta razvoja Pazina.

Idući plan pazinskih utvrda nastaje 1671. (sl. 5)4. Izradio ga je habsburški topograf i stručnjak za fortifikacije Johann Friedrich Hollstein. U biti, to je dorađen Stierov plan koji detaljnije prikazuje unutrašnju strukturu dvorca te samo shematsku strukturu gradskog naselja unutar zidina.

Na svome planu Hollstein je slovnim oznakama označio pojedinačne objekte, pa prvi put saznajemo nešto i o funkcionalnoj organizaciji pazinske utvrde. lako povezan jedinstvenim zidinama, možemo vidjeti da je prostor samog kaštela bio organiziran tako da je mogao djelovati posve samostalno. Unutarnje dvorište kaštela (A) zatvarale su zasebne zidine $i$ četvrtasta kula (C) koja je kontrolirala ulaz u grad. Prostor ispred kule dodatno je obranjen posebnim zidom (H). U sklopu utvrda samog kaštela nalazio se stan grofa Auersperga (K), vojni štab (L), konačište za vojsku (M), cisterna za vodu (E) i skladište oružja (F). U kaštel se ulazilo kroz prednje dvorište (G) kraj kojeg se nalazila i kuhinja. Dakle, pravi grad u malom. Kao i onaj Stierov, i ovaj plan sadrži prijedloge o dogradnji utvrda. Odnosi se to na utvrđenja označena oznakom N, na jugozapadnom (na mjestu gdje je to predlagao i Stier) $\mathrm{i}$ istočnom dijelu gradskih zidina te na gradnju dodatnog bastiona u rubnom zapadnom dijelu grada (N).

$4 \quad$ Hrvatski državni arhiv, Zbirka nacrta, XXXI.15. 


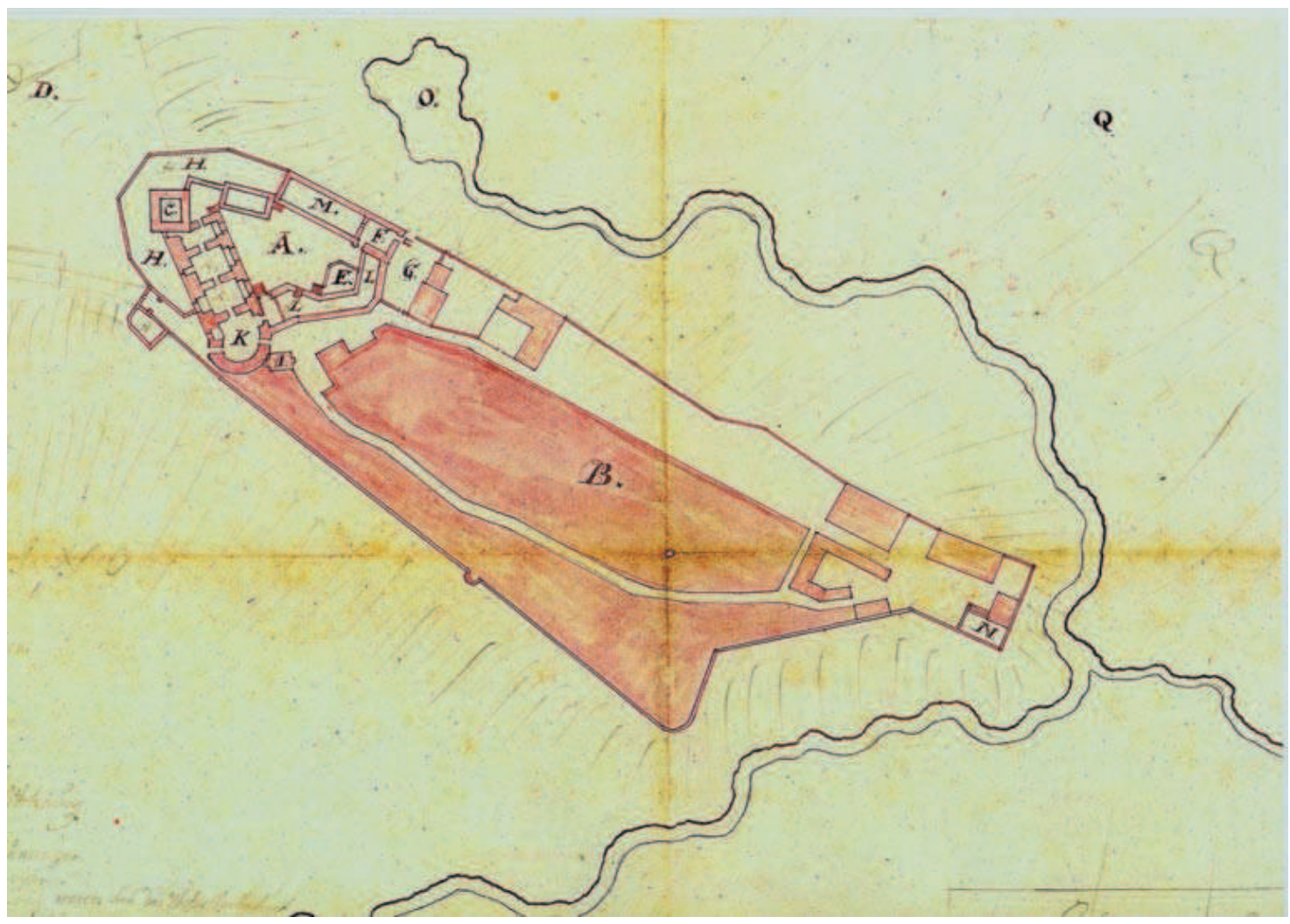

Sl. 5 Nedovršeni plan pazinskih utvrda s podgrađem, Johann Friedrich Hollstein, 1671. (Hrvatski državni arhiv)

Hollsteinov plan prvi nam put daje i naznake morfološke strukture „civilnog" utvrđenog dijela grada. Središnji dio činila je zona manje-više kompaktno izgrađenih kuća s unutrašnjim dvorištima (označeno slovom B). Druga kompaktno izgrađena zona protezala se duž sjevernog obrambenog zida. $U$ tom utvrđenom dijelu grada živjeli su uglavnom plemići i bogatiji trgovci. Uz južni zid bilo je izrađeno tek nekoliko samostojećih objekata. Zanimljivo je da je uz okruglu ulaznu kulu označena i crkvica (označena slovom I), koja je po Hollsteinu stajala s unutrašnje strane ulaza u grad, a kojoj se kasnije gubi svaki trag. Kako se u reformiranom urbaru Pazinske knežije iz 1597. pojavljuje podatak o davanjima crkvi Sv. Andrije, koja se nalazi unutar pazinskih zidina (Chiesa di San Andrea di Pisino nella Città appresso il Castello), možemo s velikom sigurnošću zaključiti da se radi upravo o toj zaboravljenoj pazinskoj crkvi ${ }^{5}$. Istu crkvu je na tome mjestu simbolom malog križa označio i Stier na svom već spomenutom planu iz 1657. godine.

lako se pazinsko podgrađe počelo formirati već tijekom 15. i 16. stoljeća, ova karta ga prvi put i izrijekom spominje (označeno je samo slovnom oznakom P). U zoni Buraja i Hrvatskog trga duž prilaznih putova kaštelu formiralo se podgrađe trgovaca i obrtnika. $\mathrm{Na}$ žalost, plan nije dorađen do kraja, pa su zone izvan gradskih utvrda tek naznačene skicom u olovci, no značajno je da Hollstein izričito spominje podgrad sa sajmišnim trgom („Vorstadt mit Marktplatz"). 


\section{Vedute Pazina - prvi prikazi naselja Pazin}

Prvi prikaz Pazina zajedno s njegovim naseljem donosi nam slovenski polihistor Johann Weickhard Valvasor. U njegovom djelu "U slavu vojvodine Kranjske“ iz 1689., odnosno u njegovoj skicnoj knjizi „Topografija Kranjske 1678.-1679.“, nalazimo vedutu Pazina koja nam prikazuje čitav grad s podgrađem (sl. 6) ${ }^{6}$. Crtana je sa strme padine iznad Jame, s pogledom na Pazin s njegove južne strane. U prvom planu vidimo kaštel s četverouglastom kulom. Ulaz u grad nalazi se s njezine suprotne strane. Plato unutar utvrđenog dijela grada u dobroj je mjeri bio utvrđen, no možemo vidjeti da su kuće u prilično lošem stanju (neke su ucrtane bez krova). Podgrađe formirano ispod kaštela razvijalo se između franjevačkog samostana i župne crkve Sv. Nikole. Kuće su ovdje uglavnom manje, u pravilu prizemnice s otvorenim dvorištima.

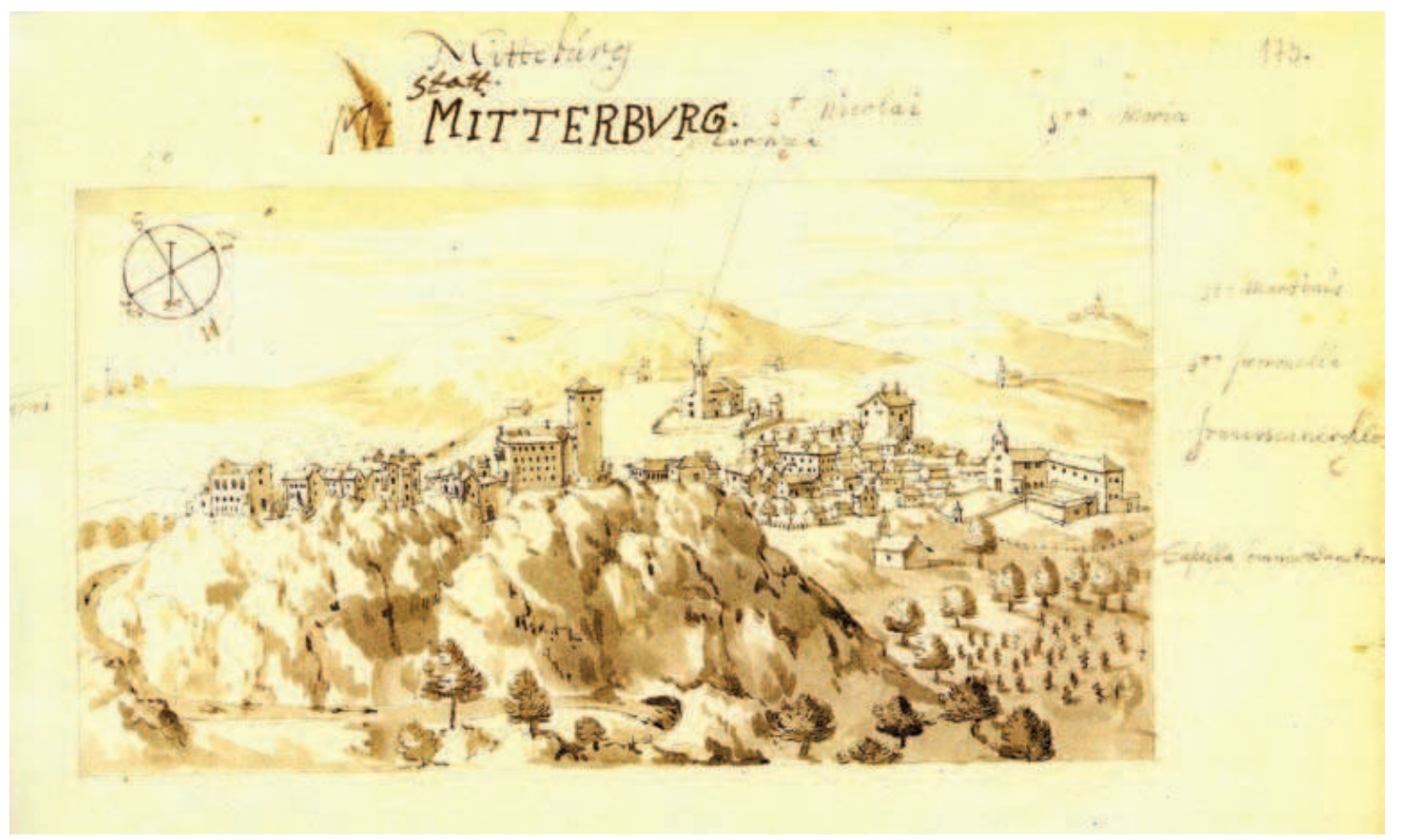

SI. 6 Rukopisna veduta Pazina Johanna Weickharda Valvasora iz njegove skicne knjige 1678.-1679. (Nacionalna i sveučilišna knjižnica, Zagreb)

Oko grada označene su pazinske crkvice Svih Svetih na Buraju, Sv. Petronele, Sv. Kuzme te crkvica Sv. Lovre, dok u pozadini kao orijentire vidimo označene crkve Sv. Marije (na Škrilinah) nedaleko od Berma te beramsku crkvu Sv. Martina. Zanimljiv je i opis koji Valvasor prilaže veduti. Obrambenu snagu samog pazinskog naselja Valvasor opisuje ovako: Taj grad Pazin nije zatvoren ni obranjen, nego je sa svih strana otvoren (misli na pograđe, op.a.)... Dvorac je doduše velik, ali se po zdanju vidi da već dugo stoji bez prave uporabe.... Južno od grada označene su šume i vinogradi koji su zauzimali razmjerno veliko područje. 0 tome Valvasor kaže: Ta se grofovija hvali sama sobom zbog svoje plodnosti. Vinogradi daju najskuplja crvena i bijela vina. Zemlja daje najbolje žito, maslina kaplje ulje, a tu se nalazi i mnogo svakovrsnih raslina i voćaka čime se inače diči Italija... (Valvasor 1689: XI, 373-377).

lako nam se na prvi pogled njegova slika Pazina može činiti pomalo idealističkom, Valvasor jasno skreće pažnju na posljedice teške krize ucrtavajući oštećene i napuštene kuće te naglašavajući u svome opisu zapuštenost kaštela. Naime, Valvasorova veduta prikazuje

6 Nacionalna i sveučilišna knjižnica u Zagrebu, sign. III.5.153. 
Pazin u vrijeme njegove vrlo teške obnove nakon višestrukih katastrofalnih stradanja. Vrijeme je to oporavka od katastrofalnih posljedica Uskočkog rata (1615.-1618.) u kojem su podjednako stradale Pazinska knežija i mletačka Istra. Procjenjuje se da je tijekom toga rata u pograničnim područjima stradalo $50-60 \%$ stanovništva i čak preko $90 \%$ stočnog fonda (Bertoša 1995: 404). Katastrofalnim štetama Uskočkog rata pridružila se jedna od najsnažnijih epidemija kuge (1631.-1632.), da bi 1653. izbila tzv. Pićanska buna prouzročena teškim fiskalnim i feudalnim pritiscima na agrarno stanovništvo Knežije. Sve to imalo je vrlo teške posljedice za ovaj izrazito agrarni prostor.

Druga veduta Pazina koju je izradio Prospero Petronio kao prilog svome djelu „Memorie sacre e profane dell'Istria“ iz 1681., nacrtana je mnogo proizvoljnije no ona Valvasorova (sl. 7). Prikazuje Pazin s podgrađem s njegove istočne strane. Ipak, iako nacrtana s mnogo propusta i deformacija, daje zanimljive podatke o fizionomiji grada i njegova podgrađa, kao i osobinama njegova prirodnog pejzaža. Petronio je očito bio znatno više impresioniran pazinskim zidinama no Valvasor, pa one zauzimaju centralni dio vedute. Unutar gradskih zidina (nacrtane su $s$ priličnim deformacijama) vidimo uglavnom kompaktno izgrađen prostor sjeverne strane utvrđenog grada te južni dio s tek nekoliko objekata koji su bili vojne namjene. Na temelju Petronijeve vedute teško je procijeniti kolika je bila stvarna gustoća izgrađenosti utvrđenog dijela grada. $U$ podgrađu označene su crkva Sv. Nikole i franjevački samostan. U pozadini vidimo Stari Pazin s crkvom Sv. Jurja. I Petronijeva veduta potvrđuje nekadašnju šumovitost padina Pazinčice. Uz obalu Pazinčice ucrtani su mlinovi koji su davali karakterističnu crtu kulturnom pejzažu pazinskog podgrađa. Ispod samih zidina nalazimo zapis "horti“. Bili su to vrtovi smješteni između zidina $i$ Pazinčice. Područje oko Pazinčice također je označeno kao obrađena polja.

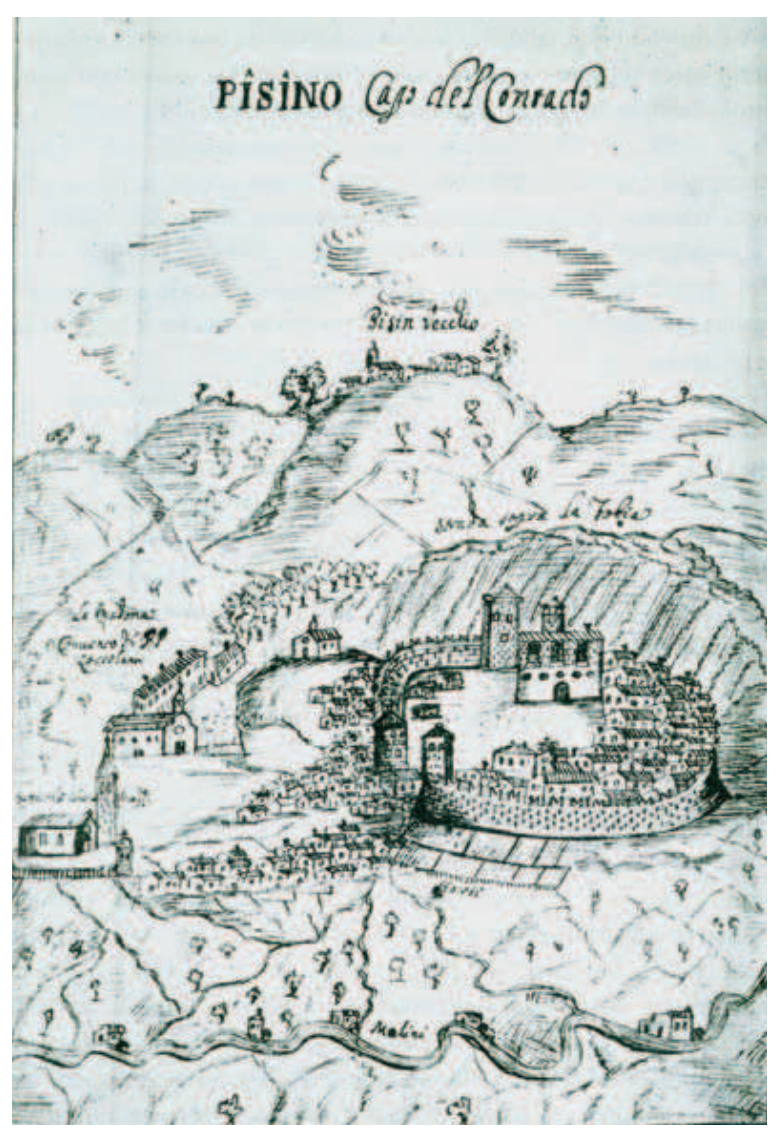

SI. 7 Veduta Pazina i okolice Prospera Petronia iz 1681.

Petronio je kao i Valvasor, pazinski kraj doživio kao izrazito pitom i plodan agrarni prostor. lako zbog znatnijih deformacija same perspektive položaj utvrda i mnogih objekata nije potpuno vjeran, Petronijeva veduta jasno oslikava osobine kulturnog i prirodnog pejsaža Pazina i njegove okolice krajem 17. stoljeća. No, za razliku od Valvasora, iz Petronijeve vedute teško možemo naslutiti razmjere agrarne krize u kojoj se razvija Pazin tijekom 17. stoljeća.

\section{Statičnost 18. stoljeća}

Tijekom 18. stoljeća, stabilizacijom granica s Osmanskim Carstvom na istoku i Mletačkom Republikom na zapadu, Habsburška Monarhija polako zapušta svoje utvrde. Tako je i Pazin 
tijekom 18. stoljeća izgubio svoj značaj kao najvažnija utvrda Pazinske knežije. Istodobno, prirodni prometni pravci, kao i putovi transhumantnih stočara i dalje su bili presječeni državnom granicom, a Pazin i njegova Knežija otkinuti od obalnog dijela Istre. Takvi nepovoljni historijsko-geografski uvjeti razvoja Pazina, uz istodobni gubitak njegovih obrambenih funkcija, prouzročili su stagnaciju u njegovu razvoju. Gubitak glavnog poticajnog čimbenika razvoja Pazina $\mathrm{i}$ istodobno nemogućnost valorizacije drugih poticajnih čimbenika razvoja, kao što je njegov iznimno povoljni prometni položaj, rezultirali su stagnacijom u njegovu razvoju. Takva situacija imala je za posljedicu i gubitak interesa habsburških kartografa za njegovo kartiranje. To potvrđuje i činjenica da je u okviru prve sustavne topografske izmjere Habsburške Monarhije, kojom su bile zahvaćene i hrvatske zemlje, upravo Pazinska knežija izmjerena posljednja, tek samim početkom 19. stoljeća.

Pazin 18. stoljeća razvijao se u okviru svojih utvrda te malenog podgrađa koje je imalo izrazito agrarne osobine. Tek samim krajem 18. i početkom 19. stoljeća utvrda postaje pretijesna, pa nakon 1815. započinje proces razgrađivanja stoljetnih bedema i tješnjeg povezivanja utvrđenog dijela grada s njegovim podgrađem. O tome nam svjedoči jedna malo poznata veduta Pietra Nobila iz 1815. na kojoj su utvrde još uvijek cjelovite (sl. 8). Kako ih na katastarskom planu iz 1820. više nema, možemo zaključiti da je razgradnja otpočela upravo u razdoblju između 1815. i 1820. godine ${ }^{7}$. Počeci razgradnje njegovih utvrda najavili su novo doba u razvoju Pazina, kada je njihov razvoj potaknut novim upravnim, gospodarskim i prometnim funkcijama.

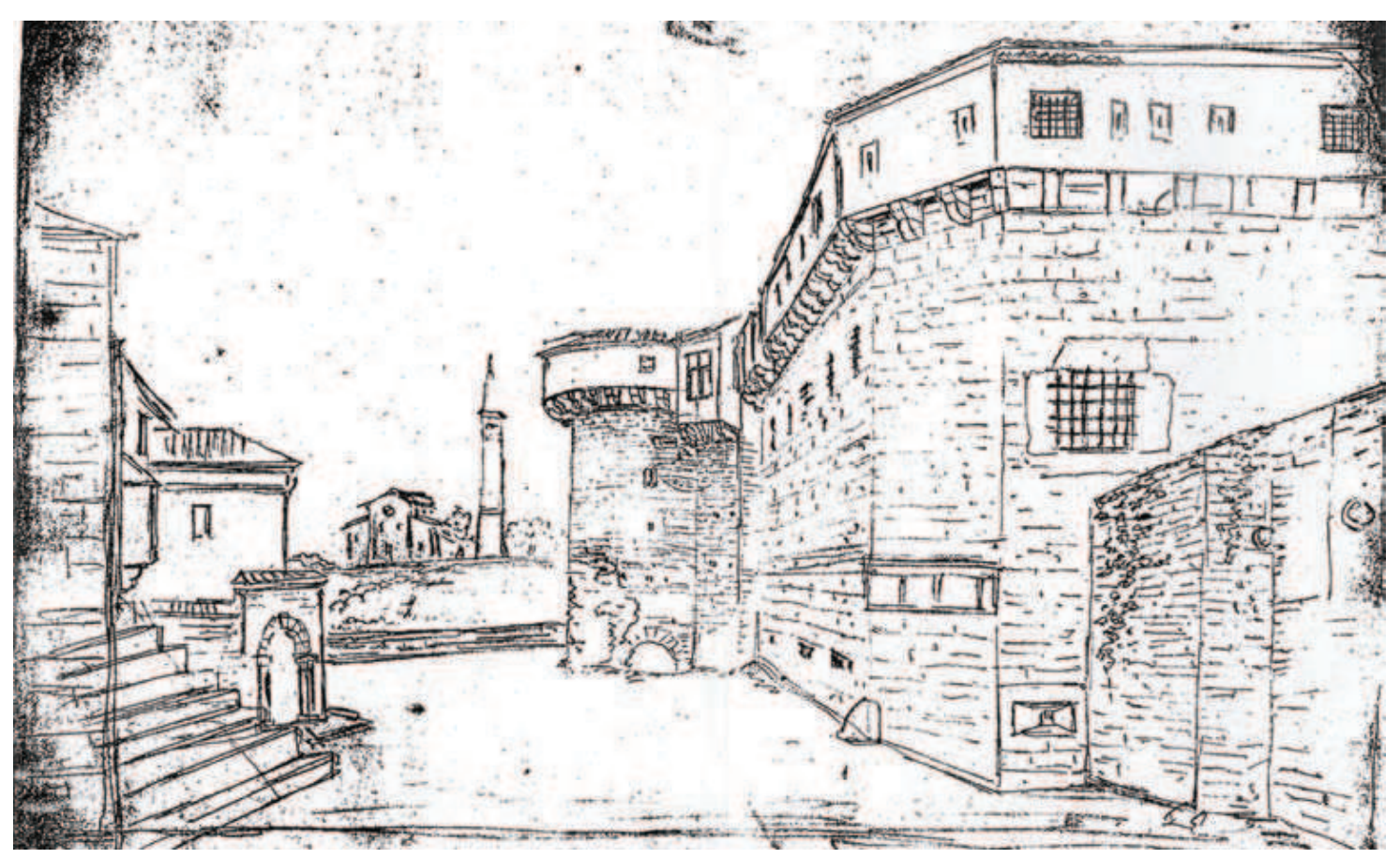

SI. 8 Pazinski kaštel na veduti Pietra Nobila iz 1815. (Državni arhiv Rijeka)

\section{Devetnaesto stoljeće - stoljeće promjena: Pazin u katastru iz 1820.}

Koliko je 18. stoljeće u razvoju Pazina bilo statično, toliko je 19. stoljeće obilježeno snažnim promjenama. Nakon višestoljetne podijeljenosti istarskog prostora na mletački i 
habsburški dio, padom Mletačke Republike 1797. čitava Istra je ušla u sastav jedne države - Habsburške Monarhije. Ponovno povezivanje stoljećima podijeljene Istre i njezino uklapanje u širi geografski prostor njezinog zaleđa, otvorili su nove razvojne perspektive pazinskom kraju. Smješten u samom središtu istarskog poluotoka, Pazin je bio prirodno križište prometnih pravaca koji su povezivali unutrašnjost s obalom. Zbog svojeg iznimnog geografskog i prometnog položaja te uz već postojeće agrarne kvalitete njegove okolice, Pazin u novoj upravnoj organizaciji postaje sjedištem Okružja. Čim je Habsburška Monarhija nakon razdoblja kratke francuske uprave ponovno zauzela mletačku i austrijsku Istru (1813.), ostvareni su preduvjeti za sustavnu katastarsku izmjeru na čitavom prostoru Monarhije ${ }^{8}$. Prva sustavna katastarska izmjera Pazina obavljena je upravo uoči nove teritorijalne organizacije Istre u kojoj će Pazin postati njezinim novim upravnim središtem9. Katastarski plan iz 1820. prikazuje nam Pazin na početku novog razdoblja njegova razvoja kada se utvrđeni dio grada otvara prema svome podgrađu koje potaknuto novim poticajnim čimbenicima razvoja postaje novim središtem Pazina (sl. 9).

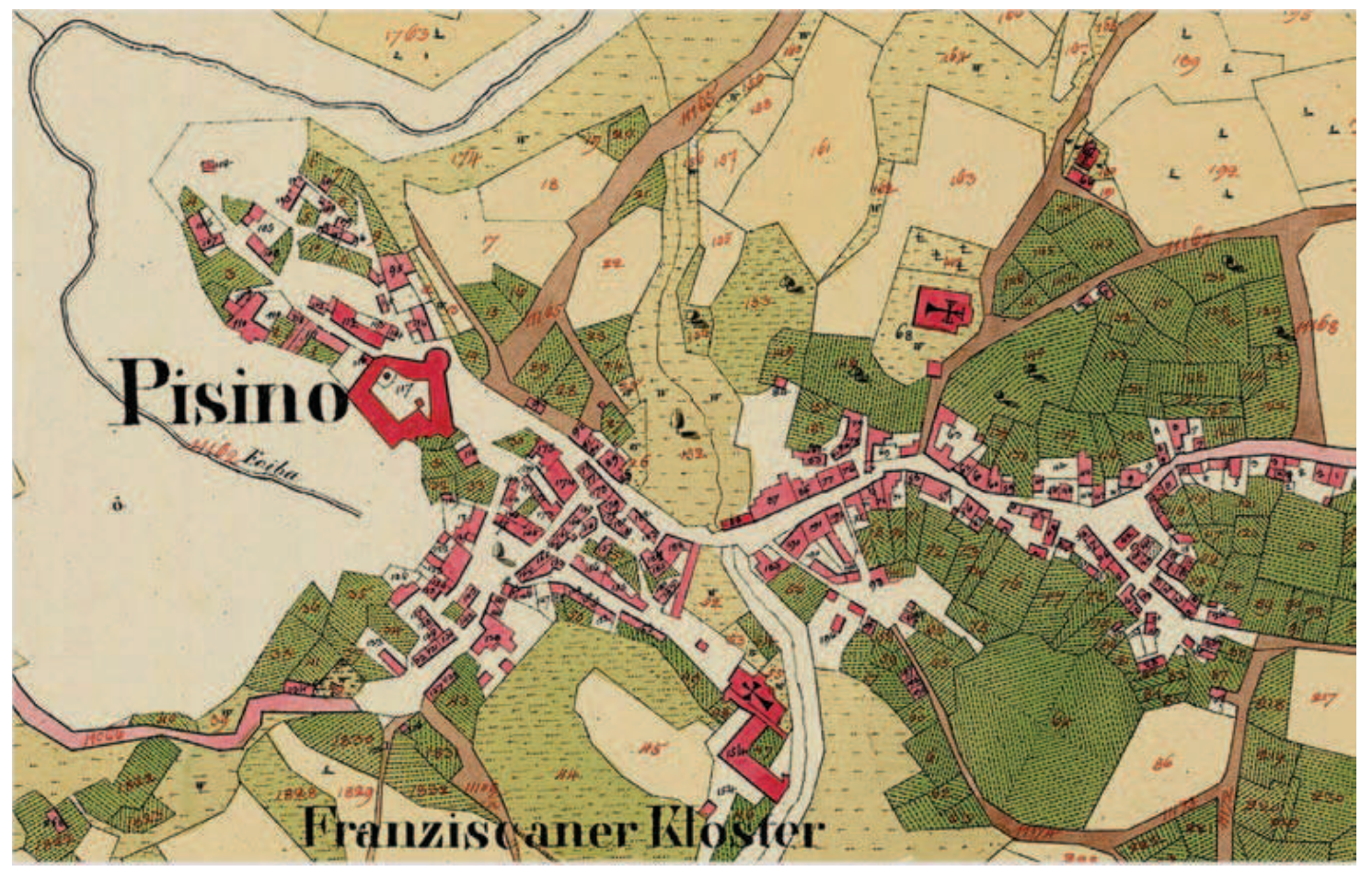

SI. 9 Katastarski plan Pazina iz 1820. (Državni arhiv u Trstu)

8 Već 1805. bilo je pokušaja da se jozefinska katastarska izmjera Monarhije prenese i na mletački dio Istre, ali su ti napori ostali bez rezultata. Prva sustavna tzv. franciskanska izmjera Istre obavljena je u razdoblju od 1817. do 1825. (Slukan Altić 2001: 10).

9 Nakon što je Habsburška Monarhija 1813. preuzela Istru, čitav je teritorij podijeljen u dva okruga: Riječki i Tršćanski. Pod Riječki okrug spadalo je 11 kotara (Rijeka, Labin, Pazin, Belaj, Lovran, Kastav, Volosko, Podgrad, Cres, Lošinj i Krk), a pod Tršćanski okrug preostali dio Istre. Gorički, Tršćanski i Riječki okrug činili su Pokrajinu Austrijsko primorje kojom je upravljao Gubernij za Primorje (1814.-1850.). Riječki okrug je već 1822. rasformiran pa su kotari Labin, Belaj, Pazin, Podgrad, Kastav, Volosko, Lovran, Krk, Cres i Lošinj otada činili novi Pazinski okrug, dok je Rijeka vraćena Hrvatskoj. Godine 1825. Pazinski i Tršćanski okrug sjedinjeni su (bez grada Trsta) u jedan pod nazivom Istarski okrug (Istrien Kreis) sa sjedištem u Pazinu (Beuc 1985: 326). Istarski okrug sa sjedištem u Pazinu organiziran je u 17 kotara: Kopar, Piran, Buje, Buzet, Lipa, Motovun, Belaj, Volosko, Poreč, Pazin, Labin, Rovinj, Vodnjan, Pula, Cres, Mali Lošinj i Krk. Tako je katastarska izmjera započela u jednom upravnom sustavu, a završila u drugom. 
Zbog specifičnih topografskih uvjeta njegova prostornog razvoja, omeđeno Jamom sa sjevera i zapada, podgrađe Pazina razvijalo se u smjeru juga i istoka. $U$ jezgri podgrađa još uvijek se jasno razlikuju dvije cjeline. Najstariji dio podgrađa nalazio se neposredno pored kaštela u predjelu Buraj, omeđen kaštelom na zapadu i tokom Pazinčice te franjevačkim samostanom na istoku s njegovim južnim krilom, dograđenim 1715. (Ujčić - Ujčić 1953: 26). Izgradnja se odvijala duž današnjih ulica Štranjga, Buraj, Vladimira Nazora i Prilaz kaštelu. Početkom 19. stoljeća u tom je prostoru formiran današnji Hrvatski trg. Oko Trga krajem 18. i početkom 19. stoljeća izgrađeno je nekoliko većih višekatnih stambenih objekata koji su imali poslovne prostore u prizemlju. Trg koji je 20-ih godina već bio gotovo formiran, tijekom bombardiranja u Drugom svjetskom ratu izgubio je tadašnju fizionomiju. Ispred franjevačkog samostana koji je omeđivao zapadni rub starog dijela podgrađa, vidimo obelisk koji su podignuli Francuzi 1816. za njihove kratke vladavine u Istri, a koji je srušen 1918. (Ujčić - Ujčić 1953: 28).

Drugu cjelinu čini predio istočno od Starog trga, između crkve Sv. Nikole i Sv. Antuna na sjeveru te Vrtlišća na jugu. Na njegovu istočnu rubu vidimo vrtove koji predstavljaju začetak pazinskog parka, koji je još na ovom planu označen kao vrt Sv. Petronile, po crkvici Sv. Petronile koja je ovdje nekad stajala. Čitav istočni dio starog Pazina ima znatno pravilniju strukturu određenu pravcem pružanja glavnih ulica. Kuće su ovdje prostranije, izgrađene u manje-više kontinuiranom nizu. Upravo će ovaj dio Pazina biti prostor najdinamičnije izgradnje grada koja će uslijediti tijekom 19. i 20. stoljeća.

I utvrđena jezgra počela je doživljavati svoju transformaciju. Obrambeni jarak sada je zatrpan, a predzid utvrde srušen. Snižena je i kvadratna kula, a kamen iz utvrda i kaštela upotrijebljen je za popločavanje pazinskih ulica (Vlaketić 1998: 130). Rušenjem zidina staroga grada napuštene su i brojne kuće koje su stajale uz same zidine, pa se morfološka struktura starog utvrđenog naselja jedva raspoznaje. Prepoznatljiv je ostao samo dio neposredno uz utvrdu te palača obitelji Rapicio. Zahvaljujući razvoju prometa i trgovine, pazinski „donji grad" postaje novim središtem zbivanja i težištem razvoja grada.

Pazin s početka 19. stoljeća, iako još uvijek pretežito agrarno naselje, nema karakterističnu fizionomiju agrarnog naselja karakteriziranu orijentacijom stambenih jedinica prema „unutra“. Pazin je usprkos svoje agrarne gospodarske podloge imao fizionomiju trgovišta čije su kuće jezgrovito okupljene duž glavnih prometnica i trgova sa sajmovima.

Sam grad Pazin 1820. imao je 200-tinjak kućnih brojeva, dok je na području čitave katastarske općine koja je obuhvaćala i okolne zaselke imao sveukupno 314 kuća u kojima je živjelo 1.615 stanovnika. Kako je uz katastarski plan Pazina kao dio katastarske dokumentacije nastao i popis čestica, zanimljivo je vidjeti koje su sve obitelji živjele u Pazinu 1820. U upisniku kao vlasnike pazinskih kuća nalazimo ova prezimena (abecednim slijedom) ${ }^{10}$ : Ambrosich, Antonich, Arich, Basillico, Bertossa, Boanno, Bursich, Callaz, Calligarich, Camus, Cattonaro, Clenovar, Colman, Corich, Cossanaz, Cosara, Cosiak, Covaz, Coverglizza, Crisanaz, Crulcich, Cuchiero, Cuduri, Delorenzi, Dequal, Dragovina, Faiman, Gabrielich, Glavich, Godina, Gortan, Grubisa, Gustin, Ivanchich, Ivich Jovich, Ladovac, Lovrenich, Luyik, Matejchich, Matievich, Matijasich, Michalich, Mizzan, Monas, Montecucoli, Mrak, Nacinovich, Orbanich, Orlich, Pacich, Paladin, Pilat, Pochusta, Pojani, Rapicio, Raunich, Richter, Sajcovich, Sollari, Segher, Sestan, Sironich, Sisevich, Slocovich, Stanovich, Sterpin, Stupar, Tirchis, Tonichich, Ucotta, Ullianich, Ursich, Valinich, Vebel, Vellan, Verbanich, Vichich, Vidmar, Vidosich, Zanca i Zanello. Tako katastar postaje važnim izvorom, ne samo za praćenje i rekonstrukciju prostornog razvoja grada, već nezaobilazan izvor i za proučavanje socijalno-demografske strukture Pazina, kao i povijesti njegovih obitelji i starih pazinskih prezimena.

10 Ovdje donosimo podatke samo za područje samog grada Pazina. 


\section{Katastarski plan iz 1875. - Pazin na pragu željezničkog doba}

Novu prekretnicu u razvoju Pazina označio je dolazak željeznice. Nije to bila samo prekretnica u prometnom povezivanju Pazina i jačanju njegovih prometnih funkcija. Željeznica je ponajviše bila gospodarska prekretnica Pazina. Dolazak željeznice pokrenuo je preobražaj Pazina iz agrarnog u gospodarsko središte središnjeg dijela Istre. Pazin na pragu željezničke faze njegova razvoja prikazuje nam katastarski plan reambulacije iz 1875., nastao godinu dana prije otvorenja željezničke pruge Divača-Pula (sl. 10). Građevinski radovi na području Pazina otpočeli su 1873., a Građevno ravnateljstvo za gradnju pruge utemeljeno je u Pazinu 1874. (Orbanić 1996: 26). Osim željezničke stanice koju prvi put vidimo na ovom planu, prema kolodvoru su izgrađene i dvije pristupne ceste, od današnjeg Šetališta pazinske gimnazije, tada glavne ceste za Rijeku te sa sjeverozapada iz produžetka Muntriljske ulice. Prugu koja je prošla južno od grada vidimo tek kao zacrtanu trasu. Sredinom 19. stoljeća Pazin je dobio novo groblje, čija je gradnja potrajala dvadesetak godina. Groblje je osnovano već 1832., no zbog tehničkih problema, u upotrebu je definitivno stavljeno tek 1852.

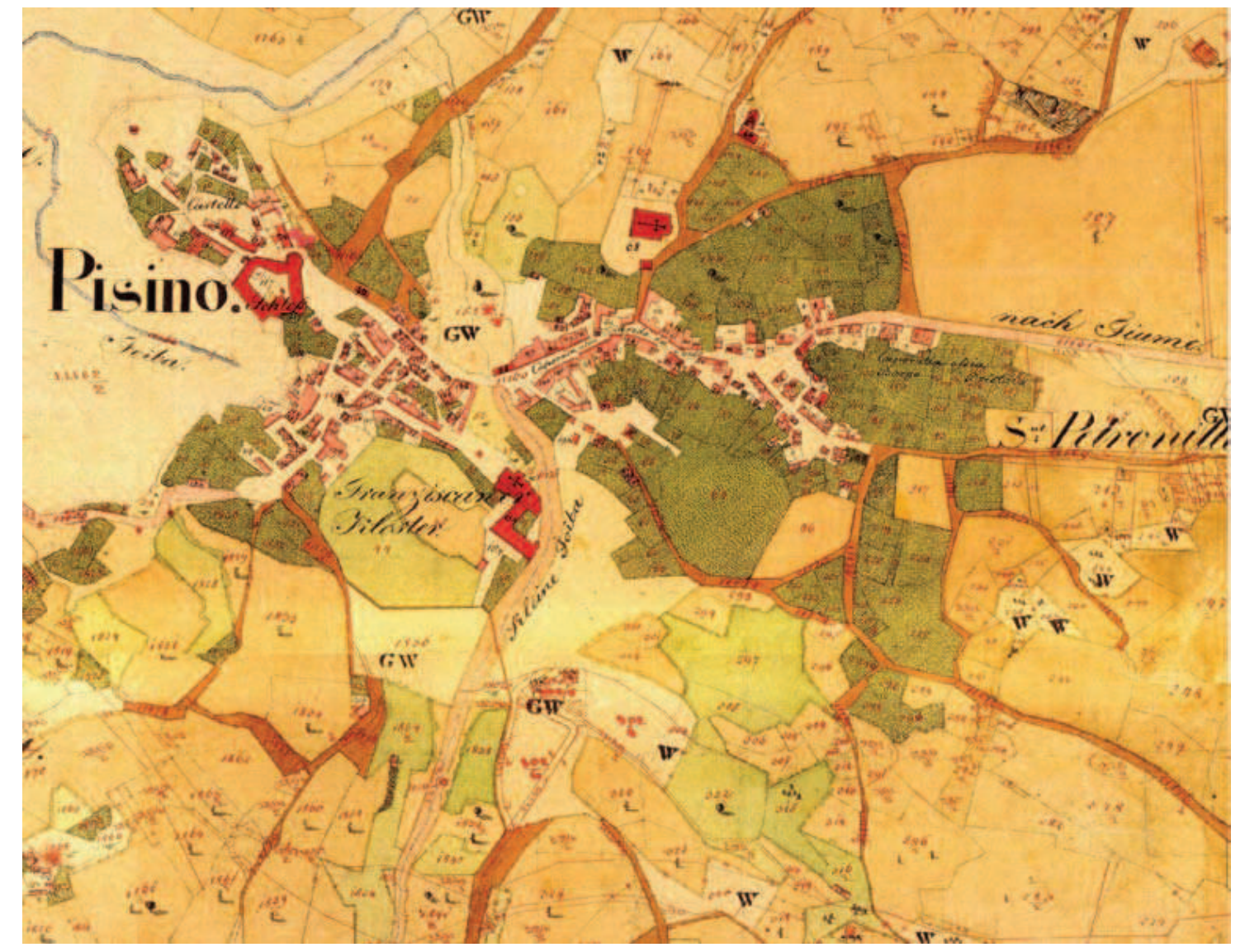

SI. 10 Katastarski plan Pazina iz 1875. (Državni arhiv u Splitu)

Od vremena prve sustavne katastarske izmjere do 1875., izgradnja grada odvijala se uglavnom prema istoku, osobito na području Dršćevke i oko Sv. Petronile. Paralelno s ulicom Pristava, tek se počinje oblikovati Nova ulica, danas Ulica Bože Milanovića. Počinje se izgrađivati i Muntriljska ulica. Pazin je tada imao nešto više od 3.000 stanovnika. 
Dolazak željeznice najavio je nova doba. Od toga vremena izgradnja i preobrazba Pazina teći će brže. Izgradnja će se odvijati na prostoru između starog središta grada i željezničke pruge koja okružuje grad $s$ njegove istočne $i$ južne strane. Pored složene topografske situacije, položaj željezničke pruge u bitnom će odrediti daljnje prostorne odrednice razvoja Pazina. Tako dolazak željeznice predstavlja prijelomni događaj koji će imati presudan utjecaj na prometni, gospodarski i urbanistički razvoj Pazina, najavljujući novo doba u razvoju grada obilježeno intenzivnijim prostornim rastom, postupnom deagrarizacijom i industrijalizacijom, koja je uz prometne i upravne funkcije danas osnovni poticajni razvojni čimbenik grada.

\section{POPIS LITERATURE}

\section{BERTOŠA 1995}

Miroslav Bertoša, „Istra: Doba Venecije (XVI.XVIII. stoljeće.)“, u: Povijest Istre 2, Pula 1995.

\section{BEUC 1985}

Ivan Beuc, Povijest institucija državne vlasti kraljevine Hrvatske, Slavonije i Dalmacije, Zagreb 1985.

\section{BRATULIĆ 1964-1965}

Vjekoslav Bratulić, „Urbari pazinskog feuda XVI. stoljeća“, Vjesnik historijskih arhiva Rijeke i Pazina, 8-9, Rijeka 1964-1965., 141-204.

\section{DE FRANCESCHI 1964}

Camillo De Franceschi, Storia documentata della Contea di Pisino, Atti e Memorie della Società Istriana di Archeologia e Storia Patria, X-XII, n.s., Venezia 1964.

\section{IVEZIĆ 1997}

Marija Ivetić, „Pazinski kaštel“, u: Pazinski kaštel i bune kmetova u XV i XVI stoljeću, Pazin 1997.

\section{KRMPOTIĆ 1998}

Ljudevit Krmpotić, Izvještaji o utvrđivanju granica Hrvatskog Kraljevstva od 16. do 18. stoljeća, Hannover-Karlobag-Čakovec 1998.

\section{MAVAR 1987}

Zofia Mavar, Pazin - Kaštel (povijest - stanje mjere): konzervatorska studija, Zagreb 1987.

\section{ORBANIĆ 1966}

Josip Orbanić, Istarske željeznice, Zagreb 1966.

\section{PETRONIO 1968}

Prospero Petronio, Memorie sacre e profane dell' Istria, Trst 1968.

\section{SLUKAN ALTIĆ 2010}

Mirela Slukan Altić, Katastar Istre (1817.1960.), Zagreb 2010.

UJČıć - UJČıĆ 1953

Tugomil Ujčić i Vitomir Ujčić, Pazin, Pula 1953.

\section{VALVASOR 1689}

Johann Weickhard Valvasor, Die Ehre des Herzogthums Crain, Nürnberg 1689.

\section{VALVASOR 2011}

Johann Weickhard Valvasor, Topografija Kranjske: 1678.-1679: skicna knjiga, Ljubljana 2011.

\section{VLAKETIĆ 1998}

Radovan Vlaketić, „Izgradnja Pazina u XIX. stoljeću“, Nova Istra, III/1, Pula 1998., 127-131. 


\section{SAŽETAK}

Pazin je nastao kao srednjovjekovno urbano središte kontinentalnog dijela Istre. Razvio se na strateški istaknutom platou iznad ponora Pazinčice, u samom srcu istarskog poluotoka, na križištu prometnih pravaca koje su povezivale Istru s unutrašnjošću kontinenta. lako se ne zna točno vrijeme njegova osnivanja, sasvim je izvjesno da je u prvim stoljećima svoga razvoja Pazin formiran kao pogranična vojna utvrda na razmeđi bizantskih i franačkih interesnih sfera. Nakon formiranja hrvatske države u koju je ušao samo istočni dio Istre, Pazin se ponovno našao u neposrednoj blizini granice. Utemeljenjem Pazinske knežije, feudalnog posjeda koji je od 1374. u posjedu Habsburgovaca, Pazin postaje važnom utvrdom na granici s Mletačkom Republikom. Okružen mletačkim posjedom na zapadu, istoku i jugu, Pazin se razvijao u kontekstu stalnih pograničnih sukoba i sporova s Rašporskim kapetanatom. Jedina prometna veza Pazinske knežije s Habsburškom Monarhijom odvijala se preko Učke i Ćićarije. Zbog takvih historijsko-geografskih ograničavajućih uvjeta razvoja na rubnom prostoru Imperija, Pazin se sve do pada Mletačke Republike razvija prije svega kao strateški važna pogranična utvrda i upravno sjedište Knežije. Utvrda kao stoljetni okvir razvoja Pazina, bila je jedan od ključnih funkcionalnih čimbenika razvoja grada, ujedno dajući mu i dominantna fizionomska obilježja. Pad Mletačke Republike i povezivanje čitave Istre u širi geografski kontekst, omogućit će Pazinu značajniju valorizaciju njegovih gospodarskih i prometnih funkcija.

Usprkos iznimnoj strateškoj važnosti Pazina, njegovi kartografski izvori razmjerno su rijetki. Vojno kartiranje habsburških topografa bilo je prvenstveno usmjereno na granično područje s Osmanskim Carstvom, dok je granica s Mletačkom Republikom ostala u drugom planu. Rijetki podaci o prostornom razvoju Pazina i njegovom utvrđivanju stoga su iznimno dragocjeni, pri čemu planovi naselja i utvrda imaju osobitu važnost. Spomenuti planovi ujedno predstavljaju i najstarije kartografske izvore Pazina. Ovaj rad pokušaj je autorice da okupi sve kartografske izvore za povijest Pazina, a njihovom analizom pridonese novim saznanjima o povijesnom razvoju Pazina i historijsko-geografskim uvjetima njegova razvoja. 


\section{SUMMARY}

\section{Historical-Geographic Conditions of the Development of Pazin: Cartographic Analysis}

Pazin originated from a mediaeval urban centre of the continental part of Istria. It developed on the strategically elevated plateau above the precipice of the Pazinčica, in the very heart of the Istrian peninsula, on the intersection of traffic directions connecting Istria to the inland areas of the continent. Although the exact time of its origin remains unknown, it is beyond doubt that in the first centuries of its development Pazin had existed as a frontier military fort in the borderland of Byzantine and Frankish interests. After the foundation of Croatia, into which only the eastern part of Istria was incorporated, Pazin once again found itself in the immediate vicinity of the border. By the establishment of the Pazin County, a feudal property in the possession of the Habsburgs since 1374, Pazin became an important fortress on the border with the Venetian Republic. Surrounded by Venetian territories in the west, east and south, Pazin developed in the context of constant borderland conflicts and disputes with the Rašpor Captaincy. The only traffic connection of the Pazin County to the Habsburg Monarchy was maintained over the Učka and the Ćićarija Mountains. Due to such historical and geographical limitations for the development in the bordering part of the Empire, Pazin had primarily developed as a strategically important borderland fort all up to the decline of the Venetian Republic. The administrative residence of the County, the Fort, as a centuries-old framework for the development of Pazin, had been one of the key functional factors in the town development, giving it the dominant physiognomic features. The fall of the Venetian Republic and connecting the whole Istria to a wider geographical context enabled a more significant role of Pazin in the valorisation of its economic and traffic functions. Despite the extreme strategic importance of Pazin, its cartographic sources are relatively scarce. Military mapping of the Habsburg topographers was primarily directed to the borderland area towards the Ottoman Empire, while the boundary with the Venetian Republic remained of secondary interest. Scarce facts on the development of Pazin and its fortification are therefore extremely valuable, especially the plans of settlements and fortifications. This essay is an attempt by the author to bring together all the relevant cartographic sources in the history of Pazin and by their analysis to give a new insight into the historical-geographic conditions of the development of Pazin.

Keywords: Pazin, Pazin County, historical geography, cartographic sources 